\title{
UVEAL MALIGN MELANOMA HASTALARININ SERUM/ PLAZMASINDA YÜKSEK MIR-454 EKSPRESYONU
}

\section{HIGH LEVEL OF miR-454 EXPRESSION IN SERUM/PLASMA OF UVEAL MALIGN MELANOM PATIENTS}

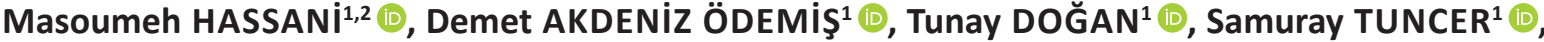 \\ Hülya YAZICI ${ }^{1,4}$ [D
}

\author{
${ }^{1}$ İstanbul Üniversitesi, Onkoloji Enstitüsü, Kanser Genetiği Bilim Dalı, İstanbul, Türkiye \\ ${ }^{2}$ İstanbul Üniversitesi, Sağlık Bilimleri Enstitüsü, Temel Onkoloji Anabilim Dalı, Kanser Genetiği Bilim Dalı, İstanbul, Türkiye \\ ${ }^{3}$ İstanbul Üniversitesi, İstanbul Tıp Fakültesi, Göz hastalıkları Anabilim Dalı, İstanbul, Türkiye \\ ${ }^{4}$ İstanbul Arel Üniversitesi, İstanbul Arel Tıp Fakültesi, Tıbbi Biyoloji ve Genetik Anabilim Dalı, İstanbul, Türkiye
}

ORCID ID: M.H.0000-0001-8976-4450; D.A.Ö. 0000-0002-2271-8481; T.D.0000-0001-5281-7360; S.T.0000-0001-7491-8613; H.Y.0000-0002-8919-0482

Atıf/Citation: Hassani M, Akdeniz Odemis D, Dogan T, Tuncer S, Yazici H. Uveal malıgn melanoma hastalarının serum/plazmasında yükseK miR-454 ekspresyonu. Sağlık Bilimlerinde Illeri Araştırmalar Dergisi 2022;5(1):14-19. https://doi.org/10.26650/JARHS2022-981726

Öz

Amaç: Uveal malign melanoma (UMM) kötü prognoza sahip, yüksek metastaz eğilimi gösteren ve erken teşhisi zor bir kanser türüdür. Bu nedenle bu hastalıkta non-invaziv diyagnostik ve prognostik biyobelirteçlere intiyaç duyulmaktadır. Çalışmamızda UMM tanısı almış hastalar ile sağlıklı kontrollerin periferik kan örneklerindeki miR-454 düzeyi ve ilgili molekülün diyagnostik ve prognostik bir biyobelirteç olma özelliği taşıyıp taşımadığı araştırılmıştır.

Gereç ve Yöntem: Bu çalışma İstanbul Üniversitesi, İstanbul Tıp Fakültesi, Göz Hastalıkları Anabilim Dalı ile Onkoloji Enstitüsü'ne başvuran, 72 UMM’li hasta ve bu hasta grubu ile yaş, cinsiyet ve etnik köken açısından eşleştirilmiş 72 sağlıklı kontrolden oluşan bir katılımcı grubunun periferik kan örnekleri kullanılarak gerçekleştirilmiştir. Periferik kan örneklerine ait serum/plazmalardan cell free RNA (cfRNA) izolasyonu yapılarak miR-454 ifade düzeyi gerçek zamanI Polimeraz Zincir Reaksiyonu (GZ-PZR) ile analiz edilmiştir. Referenas gene göre belirlenen miR-454 ekspresyon düzeyi hasta ve sağlıklı kontroller ile karşılaştırılarak değerlendirilmiştir.

Bulgular: Uveal malign melanoma ve sağlıklı kontrol grupları arasında yapılan incelemede, miR-454 ifade düzeyinin sağlıklı kontrollere göre hasta grubunda 4,14 kat arttığı ve istatistiksel olarak anlamlı olduğu saptanmıştır. Çalışmada miR-454 ifade düzeyi ile sigara ve alkol kullanımı arasında anlamlı bir ilişki olduğu gösterilmiştir. Daha sonra miR-454'ün hedef mRNA'ları biyoinformatik araçlarla incelenmiş ve miR-454'ün kanserde tümör baskılayıcı ve onkogenik fonksiyonlara sahip olduğu anlaşılmıştır.

Sonuç: Çalışmamız, daha önce çeşitli hücre hatlarında ve UMM tümör dokusunda yüksek ifade düzeyine sahip olduğu bildirilen miR-454'ün UMM hastalarının serum/plazmasında da yüksek düzeyde ifade edildiğini göstermiştir. Periferik kan dolaşımında, özellikle serum/plazmada araştırılan miR-454 ifade düzeyinin UMM'de diyagnostik ve prognostik biyobelirteç olarak kullanılabileceğini ve önemli bir terapötik hedef olarak değerlendirilebileceğini düşündürmektedir.

Anahtar Kelimeler: Uveal Malign Melanoma, MikroRNA-454, periferik dolaşım, serum, plazma, biyobelirteç

\section{ABSTRACT}

Objective: Uveal malignant melanoma (UMM) is a cancer type that has a poor prognosis and high metastasis tendency and is difficult to diagnose early. Therefore, non-invasive diagnostic and prognostic markers are needed in this disease. In the study, it was investigated the expression level of miR-454 in serum /plasma samples of UMM patients and also evaluated the feature of a diagnostic and prognostic biomarker of miR-454.

Material and Method: This study was performed on peripheral blood samples from 72 patients with UMM and 72 healthy controls matched for age, sex, and ethnicity, who applied to Istanbul University, Istanbul Faculty of Medicine, Department of Ophthalmology and Oncology Institute. MicroRNA-454 expression level in cell-free RNA (cfRNA) isolated from serum/plasma was investigated by the Real-Time PCR (RT-PCR). The expression level of miR-454 determined according to the reference gene was evaluated by comparing it with patients and healthy controls.

Results: It was found that the expression level of miR-454 increased 4.14 times in the patient group compared to the healthy controls, and it was statistically significant. In the study, it was shown that there is a significant relationship between miR-454 expression level and smoking and alcohol intake. When the mRNAs targeted by the miR-454 molecule were examined via bioinformatic tools and, it was understood that the relevant miRNA had a repressing feature and accordingly assumed the role of an oncogene.

Conclusion: Our study has shown that miR-454, which was previously reported to have high expression levels in cell lines and UMM tumor tissue, is also found at high levels in the serum/plasma of UMM patients. The results suggest that miR-454 can be a diagnostic and prognostic biomarker in uveal malignant melanoma and can be considered as a important therapeutic target.

Keywords: Uveal Malignant Melanoma, MicroRNA-454, peripheral circulation, serum, plasma, biomarker

Sorumlu Yazar/Corresponding Author: Hülya YAZICI E-mail: hulayayazici67@gmail.com; hy2188@istanbul.edu.tr

Başvuru/Submitted: 12.08.2021 • Revizyon Talebi/Revision Requested: 06.09.2021 • Son Revizyon/Last Revision Received: $13.09 .2021 \bullet$ Kabul/Accepted: 14.10.2021 Online Yayın/Published Online: 27.01.2022 


\section{GiRiş}

Uveal malign melanoma (UMM) yetişkinlerde göz içinde oluşan, hastaların görme yeteneğini ve buna bağlı olarak yaşam kalitesini ciddi anlamda bozan bir kanser türüdür (1). Amerika Birleşik Devletleri'nde yılda 2000 yeni UMM vakası bildirilmektedir (5). Kötü prognoza sahip bu tümör, hastalığın erken aşamalarında metastaz yapmakta ve sağkalımı kısaltmaktadır $(2,3)$. Günümüzdeki tedavi olanaklarıyla bile hastaların \%50'si metastaza bağlı olarak hayatını kaybetmektedir (4). Uveal malign melanoma karaciğer metastazı için yüksek potansiyele sahip olan bir malignitedir (6). Uveal malign melanoma göz içinde iris, siliar cisim ve yüksek oranda koroid bölgesine yayılmaktadır. Bazı kaynaklara göre çok nadir de olsa konjonktiva bölgesinde de yer aldığı ve kutanöz melanom olarak sınıflandırıldığı da bildirilmiştir $(7,8)$. Konjonktiva bölgesinde yer alan bu melanomlar bazı kaynaklarda ise oküler melanoma sınıfinda değerlendirilmektedir. (9, 10). Hastalığın yayılım şekli ve metastatik özellikleri hastalar için hayati tehlike arz etmekte ve UMM hastalarının \%40-50'si metastaz nedeniyle birkaç ay içerisinde hayatlarını kaybetmektedirler (11).

Uveal malign melanomanın klinik muayenede neredeyse \%100 doğrulukla teşhisi mümkün olmasına rağmen (12), birçok hastada tümör gözden kaçırılmaktadır ve bu durum geç teşhis edilmesine veya yanlış tanı koyulmasına neden olmaktadır (13). Anatomik konumu ve siliyer cisimlerin yüksek hareket kabiliyetine sahip olması nedeniyle UMM teşhisinde zorluklar bulunmaktadır. îlave olarak, bu bölgede damar ağının yoğun olması kötü prognozlu ekstravasküler matriks paterninin oluşmasına ve UMM'nin yüksek metastatik potansiyele sahip olmasına neden olmaktadır $(14,15)$. Uveal malign melanomlu hastaların tanı anında yaklaşık \%50'sinde metastaz gerçekleşmiş durumdadır (16). Yüksek oranda metastaz yapma eğilimine sahip bu kanserin uzak metastazı hematojen yayılımla ve \%90-95 oranında karaciğere olmaktadır. Uzak metastaz gelişiminin önemli bir nedeni, ilk tanı anında dolaşımda bulunan tümör hücreleridir (17). Başka bir deyişle, genelde hastaların \%50'sinde tümör teşhisi esnasında tümör hücreleri zaten yayılmıştır (18). Bu nedenle gerek UMM tanısında gerekse hastalığın takibinde yeni noninvaziv veya minimal-invaziv yöntemlerle elde edilebilecek yüksek hassasiyete ve özgüllüğe sahip biyobelirteçlere ihtiyaç duyulmaktadır.

Literatürde UMM ile ilgili olan genetik ve epigenetik araştırmaların son derece kısıtlı olması nedeniyle bu hastalıkla ilişkili olabilecek biyobelirteçlerin ve terapötik hedeflerin araştırması yüksek önem arz etmektedir.

Klinikte UMM teşhisinde olabilecek yanlış negatif ve yanIış pozitif sonuçları azaltmak amacıyla günümüzde serum ve plazmada diyagnostik ve prognostik önemi olan miRNA'ların araştırılması gündemde olan bir konudur. İlaveten dolaşımdaki miRNA araştirılması son derece hassasiyet ve özgünlüğe sahip olmakla birlikte invaziv olmayan bir metod olması ve hastalığın her aşamasını izleme imkânı taşıması açısından değerlidir (19-21). MikroRNA'lar, küçük protein kodlamayan RNA'ların bir üyesidir ve yaklaşık olarak 22 nükleotid içermektedirler. Gen anlatımının baskılanması ve hedef mRNA'ların transkripsiyon sonrası aktivitelerinin düzenlenmesi gibi rolleriyle kanser progresyonunda önemli rollere sahip oldukları düşünülmektedir. Hücredeki önemli yolaklarda, gerek hücre çoğalması, gerekse farklılaşma ve programlı hücre ölümü aktivitelerini etkisi altına alarak hücrelerin malign dönüşümüne katkı sağlamaktadır (22, 23). Birçok kanserde olduğu gibi UMM'nin ilerlemesinde de onkogen ve tümör baskılayıcı genlerin çok aşamalı genetik ve epigenetik değişimlere maruz kalması söz konusudur. Yapılan güncel araştırmalara göre küçük kodlanmayan RNA'ların UMM gelişiminde rolü olduğu bildirilmiştir (24). Farklı mikroRNA'ların çeşitli UMM hücre hatları ve tümör dokusunda anlatım seviyelerinin normal hücre ve dokulara kıyasla farklılıklar gösterdiği saptanmıştır $(12,25,26)$. Bu çalışmalardan çıkan sonuçlar birçok miRNA'nın UMM için biyobelirteç ve/veya terapötik hedef olarak kullanılabileceğine işaret etmektedir (27).

Tümör dokusunda miR-454'ün ekspresyonunun incelendiği bir çalışmada ise söz konusu miRNA molekülünün PTEN genini doğrudan hedef aldığı gösterilmiş ve bu durumun hücre proliferasyonu ve invazyonunda etkili olduğu bildirilmiştir (12). Bahsi geçen çalışmada miR-454'ün araştırıldığı hücre hatlarına ilave olarak kısıtlı sayıda insan tümör doku ve normal dokusunda miR-454'e ilişkin anlamlı veriler de bildirilmiştir. Buna karşılık, literatürde miR-454'ün diyagnostik ve prognostik önemini belirlemek üzere insan periferik kan dolaşımında plazma ya da serum örneklerindeki düzeyini ele alan bir çalışma bulunmamaktadır.

Sunulan çalışmada, miR-454'ün ifade düzeyinin UMM'de diyagnostik ve prognostik bir biyobelirteç olarak kullanılabilirliğinin değerlendirilmesi amaçlanmıştır. Çalışmamızda miR-454'ün, ifade düzeyi, toplam 144 bireyden oluşan deney grubunda UMM'li hastalar ile hasta grubu ile yaş, cinsiyet ve etnik köken açısından eşleştirilmiş sağlıklı kontrol grubuna ait katılımcıların periferik kanlarından elde edilen serum/plazma örneklerinde araştırılmıştır.

\section{GEREÇ VE YÖNTEM}

Gereç: Bu çalışma, İstanbul Üniversitesi, İstanbul Tıp Fakültesi, Klinik Araştırmalar Etik Kurulunun 13.09.2019 tarihli toplantısında 182634 sayılı yazı ile onay alınmış olup İstanbul Üniversitesi, Onkoloji Enstitüsü, Temel Onkoloji Anabilim Dalı ve İstanbul Tıp Fakültesi, Göz Hastalıkları Anabilim dalına başvuran ve UMM tanısı almış hastalar üzerinde gerçekleştirilmiştir. Çalışma grubu 2019 yılında 5 ay içerisinde, İstanbul Üniversitesi, Göz Hastalıkları Anabilim dalı polikliniğine başvuru yapan 72 uveal malign melanomlu hasta ile hasta popülasyonu ile yaş ve cinsiyet olarak eşleştirilmiş, kendisinde ve ailesinde üç jenerasyon geriye dönük olarak kanser hastalığı bulunmayan 72 sağlıklı bireyden oluşan kontrol ve deney gruplarından oluşturulmuştur. Çalışmaya dâhil edilen tüm bireyler, bilgilendirilmiş onam formunu imzaladıktan sonra gönüllü olarak çalışmaya dahil olmuşlardır.

Yöntem: Hasta ve sağııkı kontrol gruplardan alınan periferik kan örneklerinden öncelikle plazma/serum ayrıştırılmış ve ardından total cfRNA izole edilmiştir. Elde edilen RNA örneklerinden miR- 
454'e özgü cDNA sentezlenmiştir. MikroRNA-454 ve U6 referans geninin düzeyleri hasta ve sağlıklı kontrol örneklerinde GZ-PZR yöntemiyle analiz edilmiştir. Hasta ve sağııkı kişilerden oluşan kontrol grupları arasındaki miR-454'ün ifade düzeyi, miR-U6 kontrol geni ile karşılaştırılmıştır. Her bir örneğin ekspresyon seviyeleri Ct (Threshold Cycle = Eşik döngüsü) değerleri üzerinden hesaplanmıştir.

\section{BULGULAR}

Çalışmamızda UMM'li hastalar ( $n=72)$ ve sağlıklı kontrol $(n=72)$ grubu olmak üzere toplam 144 bireyin periferik kanlarından elde edilen serum/plazma örnekleri kullanıldı. Hastaların yaş ortalaması 54,68 $( \pm 13,69)$; sağlıklı kontrol grubunun yaş ortalaması ise $54,25( \pm 13,24)$, hastaların tanı yaşı ortalamasının ise $48,19( \pm 12,97)$ olduğu görüldü. Çalışmada karşılaştırılan gruplar arasındaki yaş ortalamaları arasında istatistiksel bir fark bulunmamakta, gruplar yaş açısından benzer dağılmaktaydı. Hasta ve kontrol grubuna ait demografik ve klinik özelliklere ilişkin tüm bilgiler Tablo 1'de verildi (Tablo 1).

MikroRNA ifade farklıııları (2- $\Delta \Delta \mathrm{Ct}$ ) formülü kullanılarak değerlendirildi. Bu yöntemde hedef gen ile referans genin arasında olan değişik $\Delta$ Ct hasta ve kontrol grubu için ayrı ayrı hesaplandı. Ardından her bir hasta örneğine ait $\Delta C t$ değerinden sağlıklı gruba ait ortalama $\Delta C t$ değeri belirlendi ve her bir hasta örneğine ait $\Delta \Delta \mathrm{Ct}$ değeri bulundu. Bu değer 2- $\Delta \Delta \mathrm{Ct}$ formüle göre $\mathrm{U} 6$ gen ifadesi referans alınarak hasta grubuna ait miR-454'ün ifade düzeylerinin kontrol grubuna göre ne kadar oranda arttğı ya da azaldığı hesaplandı.

Tablo 1: Hastaların Demografik ve Klinik Özellikleri

\begin{tabular}{|c|c|c|}
\hline & Özellikler & Hasta Sayısı ve \\
\hline & Схетाке & Yüzdesi (n / \%) \\
\hline \multirow{2}{*}{ Yaş } & $\leq 60$ & $26(\% 36,11)$ \\
\hline & $>60$ & $46(\% 63,89)$ \\
\hline \multirow{6}{*}{$\begin{array}{l}\text { Histolojik } \\
\text { Tanı }\end{array}$} & İris Melanoma & $7(\% 9,72)$ \\
\hline & Siliyar Cisimler Melanoma & $1(\% 1,39)$ \\
\hline & Koroid Melanoma & $56(\% 77,78)$ \\
\hline & Konjonktival Melanoma & $3(\% 4,17)$ \\
\hline & İris + Siliyar Cisimler Melanoma & $1(\% 1,39)$ \\
\hline & $\begin{array}{c}\text { Koroid + Siliyar Cisimler } \\
\text { Melanoma }\end{array}$ & $4(\% 5,55)$ \\
\hline \multirow{2}{*}{ Evre } & Erken Evre $(\mathrm{I}, \mathrm{II})$ & $38(\% 52,77)$ \\
\hline & İleri Evre (III, IV) & $34(\% 47,23)$ \\
\hline \multirow{2}{*}{ Metastaz } & Var & $4(\% 5,55)$ \\
\hline & Yok & $68(\% 94,45)$ \\
\hline Riskli & Var & $31(\% 43,06)$ \\
\hline Meslek & Yok & $41(\% 56,94)$ \\
\hline \multirow{2}{*}{$\begin{array}{l}\text { Sekonder } \\
\text { Primer } \\
\text { Tumor }\end{array}$} & Var & $4(\% 5,55)$ \\
\hline & Yok & $68(\% 94,45)$ \\
\hline Siliyar & Var & $6(\% 8,33)$ \\
\hline Tutulumu & Yok & $66(\% 91,67)$ \\
\hline Sigara & Kullanıyor & $36(\% 50,00)$ \\
\hline Kullanımı & Kullanmıyor & $36(\% 50,00)$ \\
\hline
\end{tabular}

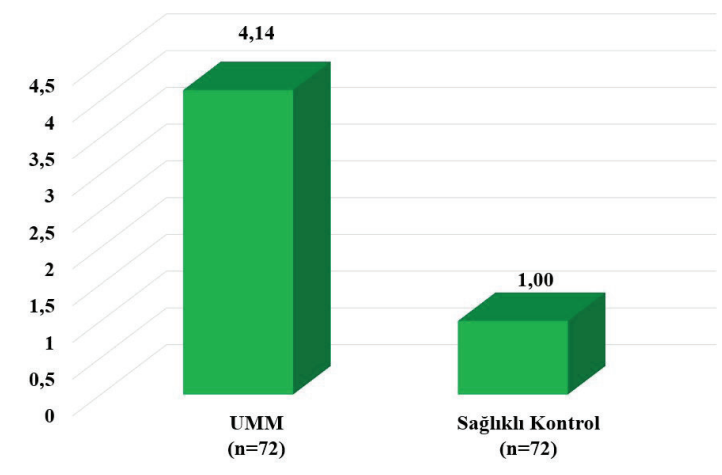

Şekil 1: Uveal Malign Melanomlu Hastaların ve Sağlıklı Kontrollerin miRNA İfade Düzeyi

Uveal malign melanomlu hastaların, sağ ıklı gruba göre ifade düzeylerindeki (2- $\Delta \Delta \mathrm{C} \mathrm{t})$ artş̧ veya azalışı gösteren grafikler Şekil 1 'de verildi (Şekil 1). Hasta verilerinin Fold \& Change ( $|F C| \geq 2$ ) değeri göz önüne alındığında, gen ifade düzeylerinin 2 kattan fazla arttı̆ı görüldü (Şekil 1). Bu sonuçlara göre hastalardaki miR454 gen ifade düzeyi sağlıklı kontrol grubu ile karşılaştırıldığında miR-454'ün hastalarda 2- $\Delta \Delta \mathrm{Ct}=4,14$ kat arttı̆̆ saptandı.

SPSS v21.0 programı ile yapılan istatistiksel analizlere göre; gruplar arasındaki dağılımın normallik varsayımı KolmogorovSmirnov ve Shapiro Wilk testleri ile değerlendirildi. Normallik varsayımı sonuçlarına göre $p<0,05$ olduğu için, grupların normal dağılım göstermediğine ve verilerin incelenmesinde parametrik olmayan Mann-Whitney $U$ testinin kullanılmasının uygun olduğuna karar verildi. Mann-Whitney $U$ testi ile yapılan değerlendirmeye göre hasta ve kontrol grupları arasındaki $2-\Delta \Delta \mathrm{Ct}$ değerleri baz alınarak yapılan hesaplamalarda araştırdığımız miRNA-454 ifade düzeyinin hasta gruplarında sağlıklı kontrollere göre istatistiksel açıdan anlamlı $(p<0,05)$ olduğu görüldü. Çalışmamızda miRNA-454 için elde edilen $p$ değerinin $p=0,005$ olduğu hesaplandı.

Uveal malign melanomalı hastalarda miR-454 ifade düzeyi ile hastaların cinsiyeti, tanı yaşları, klinik evreleri, tümör boyutu, metastaz durumu, cerrahi, radyasyon ya da kemoterapi gibi tedavi seçenekleri, herhangi bir riskli meslek grubunda çalışıp çalışmadığı, sigara ve alkol kullanımı gibi değişkenler arasındaki ilişki ayrıca Mann-Whitney U testi ile değerlendirildi. Söz konusu miR-454 ile alkol ve sigara kullanımı hariç olmak üzere yukarıda sayılan diğer tüm değişkenler arasında istatistiksel anlamlılık saptanamazken, miR-454 ekspresyon düzeyi ile sigara ve alkol kullanımı arasında yapılan karşılaştırmada p değerlerinin sırasıyla 0,009 ve $0,026(<0,05)$ olduğu ve ilişkinin istatistiksel olarak anlamlı olduğu görüldü (Tablo 2 ). 
Tablo 2: MikroRNA-454 İfade Düzeyleri ile Sigara ve Alkol Kullanımı Arasındaki İlişki

\begin{tabular}{lcclll}
\hline \multicolumn{4}{l}{ miRNA-454 Ekspresyon Düzeyi: } & & \\
\hline $\begin{array}{l}\text { Ekspresyon } \\
\text { Düzeyi }\end{array}$ & $\begin{array}{c}\text { Azalmış } \\
\mathrm{n}(\%)\end{array}$ & $\begin{array}{c}\text { Artmış } \\
\mathrm{n}(\%)\end{array}$ & $\begin{array}{l}\text { Toplam } \\
\mathrm{n}(\%)\end{array}$ & \\
Sigara Kullanımı & & & & \\
Yok & $2(\% 2,8)$ & $33(\% 45,8)$ & $35(\% 48,6)$ & $37(\% 51,4)$ & \\
Var & $11(\% 15,3)$ & $26(\% 36,1)$ & & \\
Toplam $\mathrm{n}(\%)$ & $13(\% 18,1)$ & $59(\% 81,9)$ & $72(\% 100)$ & $\mathrm{p}=0,009$ \\
Alkol Kullanımı & & & & \\
Yok & $11(\% 15,3)$ & $58(\% 80,6)$ & $69(\% 95,8)$ & $3(\% 4,2)$ & \\
Var & $2(\% 2,8)$ & $1(\% 1,4)$ & & \\
Toplam $\mathrm{n}(\%)$ & $13(\% 18,1)$ & $59(\% 81,9)$ & $72(\% 100)$ & $\mathrm{p}=0,026$ \\
\hline
\end{tabular}

MikroRNA-454 hedef genleri "mirTarBase" ve "TargetScan" veri tabanları kullanılarak belirlendi ve miR-454'ün önemli hedef genleri olan MDM4, PTEN, WNT1, WNT2B, MAPK1, MET, $H G F$ arasında olası anlamlı etkileşim için STRING analizi yapıldı. STRING analizi sonuçlarına göre miR-454'ün hedef proteinleri için en fazla etkileşim MET ile HGF molekülleri ve PTEN ile MDM4 molekülleri arasında olduğu görüldü. Ayrıca bu analizde en yakın sekans benzerliği olan WNT1 ve WNT2B moleküllerinin de miR-454 ile yakın etkileşimde oldukları görüldü $(p<$ $0,05)$ (Şekil 2).

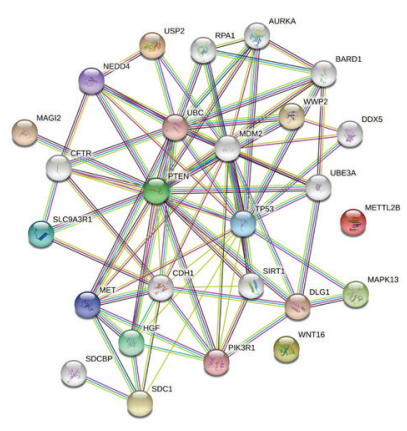

Şekil 2: MikroRNA-454'ün Hedef Genleri için Yapılan STRING Analizi ( $p$ değeri: 0,000129)

İncelediğimiz miR-454 molekülünün aday biyobelirteç olarak tanısal performansını diğer bir değişle UMM tanılı hasta ve sağlıklı kontrol grubunu ayırt edebilme gücünü gösterebilmek amacı ile Reciever Operator Characteristics (ROC) analizi gerçekleştirildi ve miRNA-454 için belirlenen ROC-AUC değerleri \%95 Cl (Güven Aralığı) aralığında belirlendi (Şekil 3). Bu sonuçlara göre uveal malign melanomalı hastaların tanısında miRNA-454 molekülünün tanısal gücünün istatistiksel olarak anlamlı olduğu saptandı $(p=0,000)$.

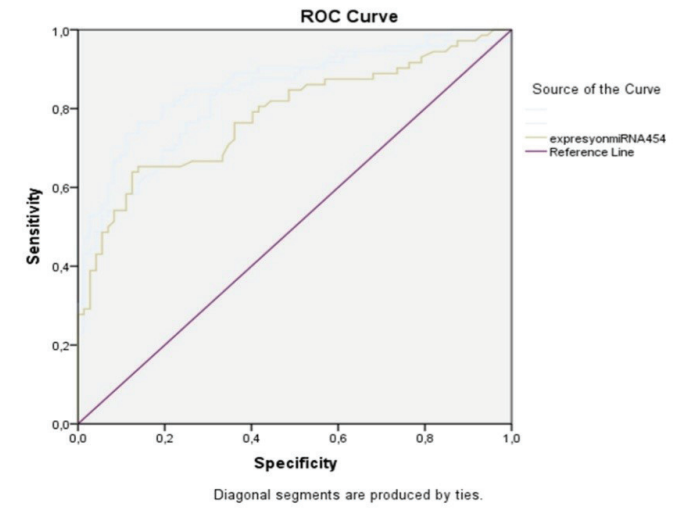

Şekil 3: MikroRNA-454 Ekspresyonunun ROC Analizli

\section{TARTIŞMA}

Günümüzde yapılan araştırmalarda insan genlerinin ekspresyon verileri, kanser oluşumu ve ilerlemesinde miRNA'ların önemli bir role sahip olduğunu göstermektedir (28-31). Yapılan birçok çalışmada miRNA'ların kanserin tanı ve takibi ile terapötik ajan ya da terapötik hedef olarak kanser tedavisinde kullanılabilecek etkili moleküller oldukları bildirilmiştir (32-34). miR-454 ekspresyonunun, hepatoselüler karsinom (HCC) (35), serviks kanseri (36), meme kanseri (37) ve glioma (38) olmak üzere birçok kanser türünde de artş gösterdiği bildirilmiştir. MikroRNA-454'ün özellikle PTEN ekspresyonu üzerinden hücre proliferasyonunu etkileyerek kansinogenezde rol oynadığı ifade edilmektedir (12). Söz konusu miRNA'nın da farklı bir çok çalışmada UMM hücre hatları ile UMM tümör dokusu örneklerinde yüksek düzeyde anlatım yaptı̆̆ı, hücre proliferasyonu, invazyon ve metastaz ile yakından ilişkili olduğu bildirilmiştir $(12,25,26$, 39-48). Uveal malign melanom ile ilgili olarak bugüne kadar yapılan birçok çalışmada farklı miRNA'ların bu hastalıkta tümör supresor ve/veya onkogen olarak davrandığına işaret edilmektedir. Uveal malign melanomada miR-367, miR-21, miR-21a, miR-155, miR-181b, miR-92a-3p'nin UMM hücre hatları ile tümör dokusunda onkogenik etki gösterdiği belirtilirken, miR-137, mir-144, miR145, miR-296-3p ve miR-23a'nın tümör baskılayıcı role sahip olduğu bildirilmiştir (24).

Yukarıda bahsi geçen ve literatürde var olan çalışmaların çoğu UMM hücre hatlarında ve tümör doku örneklerinde yapılmış olup hastalara ait serum/plazma örneklerindeki miRNA'ların ekspresyon düzeyinin araştırıldığı bir çalışma literatürde yer almamaktadır $(12,25,26,39-48)$.

Uveal malign melanomlu ve sağlıklı kişilerin periferik kanına ait serum/plazma örneklerinde yaptığımız çalışmada daha önce UMM'li hastaların tümör dokusunda yüksek düzeyde ifade edildiği gösterilen miR-454'ün ifade düzeyinin hastalara ait serum/plazma örneklerinde sağlıklı kontrollere göre 4,14 kat artth̆̆ı ve bu farkın istatistiksel açıdan anlamlı olduğu saptanmıştır ( $p=0,005)$. Uveal malign melanomlu hastaların serum/ plazmasında gösterilen yüksek miR-454 ifade düzeyinin, hedef mRNA'ları baskılaması nedeniyle onkogenik etki gösterdiği düşünülmektedir (12). Çalışmamızda sigara ve alkol kullanımı arasında istatistiksel anlamlılık gösteren miR-454'ün gerek pri- 
mer hastalığı olan gerekse metastatik hastalığı olan kişilerin serum/plazma örneklerinde de benzer düzeyde eksprese olduğu belirlenmiştir. Bu bulgular miR-454'ün non-invaziv tanısal ve prognostik öneme sahip olabilecek bir biyolobelirteç olabileceğini düşündürmektedir.

Çalışmamızda istatistiksel olarak anlamlı ROC analizi verileriyle serum/plazmada yüksek düzeyde saptanan miRNA-454'ün UMM tanılı hastaların sağlıklı kişilerden ayırılmasında tanısal performansının yüksek olduğu saptanmıştr. Bu bulgu serum/ plazmada saptanan miR-454'ün gerek hastalığın tanısı ve takibinde non-invaziv bir biyolojik belirteç olarak kullanılabileceğini gerekse terapötik bir hedef olarak gelecekteki çalışmalarda değerlendirilmesi ve geniş çapta araştırılmasının gerektiğini düşündürmektedir.

Bu çalışma kapsamında yapılan STRING analizinde miR-454 ile en fazla etkileşim gösteren hedef proteinlerin MET ve HGF molekülleri olduğu görülmüştür. Daha önceki çalışmalarda MET ve HGF moleküllerinin HGFR-HGF etkileşimi üzerinden hücre dışı matriksten sinyalleri sitoplazmaya aktaran reseptör tirozin kinaz aktivitesi ile çoğalma, morfogenez, invazyon ve hayatta kalma dâhil birçok fizyolojik süreci düzenlediği bildirilmiştir (49). Hücre yüzeyine ligand bağlanmasının ardından, down stream sinyal moleküllerinin aktivasyonu takiben hücre içinde bulunan MET'in otofosforilasyonuyla MAPK yolağının ve PI3K-AKT-mTOR sinyal yolaklarının aktivasyonlarının gerçekleştiği bilinmektedir. Aktive olan bu yolaklar hücre proliferasyonu ile hücrenin hayatta kalmasına yol açarak kanser progresyonunda rol oynamaktadırlar. Uveal Malign melanomlu hastaların periferik kanında artış gösteren miR-454 molekülünün de bu etki mekanizmasıyla malign formasyonun gelişimine neden olduğu söylenebilir. Bundan başka, çalışma kapsamında yapılan STRING analizinde miR454'ün PTEN ve MDM4 sinyal yolunda MDM2, FOXO ve TP53 proteinleriyle, yanı sıra, WNT1 ve WNT2B gibi farklı yolaklardaki moleküllerle de etkileştiği görüldüğünden miR-454'ün karsinogenezde farklı gen yolaklarını etkileyen etkinliği son derece yaygın bir molekül olduğu düşünülmektedir.

Çalışmamız kapsamında ele aldığımız miR-454'ün periferik kan dolaşımında araştırılan ifade düzeyinin UMM hastalığında yüksek diyagnostik değere sahip olduğu ve terapötik hedef olarak değerlendirilebileceği görülmektedir. Buna karşılık söz konusu molekülün benign ve diğer malign göz tümörlerinde araştırılmamış olması bu çalışmanın en önemli kısıtları arasındadır. Söz konusu eksiklikler gelecekte yapılacak olan çalışmalarda değerlendirilecektir.

Hakem Değerlendirmesi: Dış bağımsız.

Bilgilendirilmiş Onam: Katlımcılardan bilgilendirilmiş onam alınmıştır.

Etik Komite Onayı: Bu çalışma için etik komite onayı İstanbul Üniversitesi, İstanbul Tıp Fakültesi Klinik Araştırmalar Etik Kurulu'ndan alınmıştır (Tarih: 13.09.2019, No: 182634).

Yazar Katkıları: Çalışma Konsepti/Tasarım-M.H.,H.Y.; Veri Toplama- M.H.,D.A.Ö.,T.D.,S.T.,H.Y.; Veri Analizi/YorumlamaM.H.,D.A.Ö.,T.D.,H.Y.; Yazı Taslağı- M.H.,D.A.Ö.,T.D.,S.T.,H.Y.; İçeriğin
Eleştirel İncelemesi- M.H.,D.A.Ö.,T.D.,S.T.,H.Y.; Son Onay ve SorumlulukM.H.,D.A.Ö.,T.D.,S.T.,H.Y.

Çıkar Çatışması: Yazarlar çıkar çatışması beyan etmemişlerdir

Finansal Destek: Bu çalışma İstanbul Üniversitesi Bilimsel Araştırma Projeleri Birimi tarafindan desteklenmiştir. (No: TDK-2019-35336)

Peer Review: Externally peer-reviewed.

Informed Consent: Written consent was obtained from the participants.

Ethics Committee Approval: This study was approved by the Clinical Research Ethical Committee of the Istanbul University, Istanbul Faculty of Medicine (Date: 13.09.2019, No:182634)

Author Contributions: Conception/Design of Study- M.H.,H.Y.; Data Acquisition-M.H.,D.A.Ö.,T.D.,S.T.,H.Y.; Data Analysis/InterpretationM.H.,D.A.Ö.,T.D.,H.Y.; Drafting Manuscript- M.H.,D.A.Ö.,T.D.,S.T.,H.Y.; Critical Revision of Manuscript- M.H.,D.A.Ö.,T.D.,S.T.,H.Y.; Final Approval and Accountability- M.H.,D.A.Ö.,T.D.,S.T.,H.Y.

Conflict of Interest: Authors declared no conflict of interest.

Financial Disclosure: This study was supported by Istanbul University Scientific Research Projects Unit. (No: TDK-2019-35336)

\section{REFERANSLAR}

1. Krantz BA, Dave N, Komatsubara KM, Marr BP, Carvajal RD. Uveal melanoma: epidemiology, etiology, and treatment of primary disease. Clin Ophthalmol 2017;11:279-89.

2. Shields CL, Kaliki S, Furuta M, Fulco E, Alarcon C, Shields JA. American Joint Committee on Cancer classification of posterior uveal melanoma (tumor size category) predicts prognosis in 7731 patients. Ophthalmology 2013;120(10):2066-71.

3. Shields JA, Shields CL. Management of posterior uveal melanoma: past, present, and future: the 2014 Charles L. Schepens lecture. Ophthalmology 2015;122(2):414-28.

4. Eskelin S, Pyrhönen S, Summanen P, Hahka-Kemppinen M, Kivelä T. Tumor doubling times in metastatic malignant melanoma of the uvea: tumor progression before and after treatment. Ophthalmology 2000;107(8):1443-9.

5. Materin MA, Faries M, Kluger HM. Molecular alternations in uveal melanoma. Curr Probl Cancer 2011;35(4):211-24.

6. Dithmar S, Diaz CE, Grossniklaus HE. Intraocular melanoma spread to regional lymph nodes: report of two cases. Retina 2000;20(1):76-9.

7. Koc I, Kiratli H. Current Management of Conjunctival Melanoma Part 2: Treatment and Future Directions. Turk J Ophthalmol 2020;50(6):362-70.

8. Wong JR, Nanji AA, Galor A, Karp CL. Management of conjunctival malignant melanoma: a review and update. Expert Rev Ophthalmol 2014;9(3):185-204.

9. Seregard S. Conjunctival melanoma. Surv Ophthalmol 1998;42(4):321-50.

10. Brownstein S. Malignant melanoma of the conjunctiva. Cancer Control 2004;11(5):310-6.

11. Kujala $E$, Makitie T, Kivela T. Very long-term prognosis of patients with malignant uveal melanoma. Invest Ophthalmol Vis Sci 2003;44(11):4651-9. 
12. Sun L et, Wang Q, Gao X, Shi D, Mi S, Han Q. MicroRNA-454 functions as an oncogene by regulating PTEN in uveal melanoma. FEBS Lett 2015;589(19 Pt B):2791-6.

13. McLaughlin CC, Wu XC, Jemal A, Martin HJ, Roche LM, Chen VW, et al. Incidence of noncutaneous melanomas in the U.S. Cancer 2005;103(5):1000-7.

14. Chang AE, Karnell LH, Menck HR. The National Cancer Data Base report on cutaneous and noncutaneous melanoma: a summary of 84,836 cases from the past decade. The American College of Surgeons Commission on Cancer and the American Cancer Society. Cancer 1998;83(8):1664-78.

15. Johansson CC, Mougiakakos D, Trocme E, All-Ericsson C, Economou MA, Larsson $O$, et al. Expression and prognostic significance of iNOS in uveal melanoma. Int J Cancer 2010;126(11):2682-9.

16. Yan D et, Zhou X, Chen X, Hu DN, Xiang Da Dong XD, Wang J, et al. MicroRNA-34a inhibits uveal melanoma cell proliferation and migration through downregulation of c-Met. Invest Ophthalmol Vis Sci 2009;50(4):1559-65.

17. Chen X, Wang J, Shen H, Lu J, Li C, Hu DN, Epigenetics, microRNAs, and carcinogenesis: functional role of microRNA-137 in uveal melanoma. Invest Ophthalmol Vis Sci 2011;52(3):1193-9.

18. Singh $A D$, Shields $C L$, Shields JA. Prognostic factors in uveal melanoma. Melanoma Res 2001;11(3):255-63.

19. Chen X, Ba Y, Ma L, Cai X, Yin Y, Wang K, et al. Characterization of microRNAs in serum: a novel class of biomarkers for diagnosis of cancer and other diseases. Cell Res 2008;18(10):997-1006.

20. Gilad S, Meiri E, Yogev Y, Benjamin S, Lebanony D, Yerushalmi N, et al. Serum microRNAs are promising novel biomarkers. PLoS One 2008;3(9):e3148. doi: 10.1371/journal.pone.0003148.

21. Mitchell PS, Parkin RK, Kroh EM, Fritz BR, Wyman SK, PogosovaAgadjanyan EL, Peterson A, et al. Circulating microRNAs as stable blood-based markers for cancer detection. Proc Natl Acad Sci U S A 2008;105(30):10513-8.

22. Bignotti E, Calza S,Tassi RA, Zanotti L, Bandiera E, Sartori E, et al. Identification of stably expressed reference small non-coding RNAs for microRNA quantification in high-grade serous ovarian carcinoma tissues. J Cell Mol Med 2016;20(12):2341-8.

23. Bartel DP. MicroRNAs: genomics, biogenesis, mechanism, and function. Cell 2004;116(2):281-97.

24. Yi Fan Li, Li Dong, Yang Li, Wen Bin Wei A Review of MicroRNA in Uveal Melanoma. Onco Targets Ther 2020;13:6351-9.

25. Zhang L He X, Li F, Pan H, Huang X, Wen X, et al. The miR-181 family promotes cell cycle by targeting CTDSPL, a phosphatase-like tumor suppressor in uveal melanoma. J Exp Clin Cancer Res 2018;37:15.

26. Peng J, Liu H, Liu C. MiR-155 Promotes Uveal Melanoma Cell Proliferation and Invasion by Regulating NDFIP1 Expression. Technol Cancer Res Treat 2017;16(6):1160-7.

27. Li Z, Yu X, Shen J, Jiang Y. MicroRNA dysregulation in uveal melanoma: a new player enters the game. Oncotarget 2015;6(7):4562-8.

28. Zhang B, Pan X, Cobb GP, Anderson TA. microRNAs as oncogenes and tumor suppressors. Dev Biol 2007;302(1):1-12.

29. Aughton K, Kalirai H., Coupland SE. MicroRNAs and Uveal Melanoma: Understanding the Diverse Role of These Small Molecular Regulators. Int J Mol Sci 2020;21(16):5648.

30. Catalanotto C, Cogoni C, Zardo G. MicroRNA in Control of Gene Expression: An Overview of Nuclear Functions. Int J Mol Sci 2016;17(10):1712.

31. He L, Hannon GJ. MicroRNAs: small RNAs with a big role in gene regulation. Nat Rev Genet 2004;5(7):522-31.
32. Erson AE, Petty EM. miRNAs and cancer: New research developments and potential clinical applications. Cancer Biol Ther 2009;8(24):2317-22.

33. Lagana A, Russo F,Sismeiro C, Giugno R, Pulvirenti A, Ferro A. Variability in the incidence of miRNAs and genes in fragile sites and the role of repeats and $\mathrm{CpG}$ islands in the distribution of genetic material. PLoS One 2010;5(6):e11166. doi: 10.1371/journal.pone.0011166

34. Lamy P, Andersen CL, Dyrskjøt L, Tørring N, T Ørntoft T, Wiuf C. Are microRNAs located in genomic regions associated with cancer? $\mathrm{Br}$ J Cancer 2006;95(10):1415-8.

35. Li Y, Jiao Y, Fu Z, Luo Z, Su J, Li Y. High miR-454-3p expression predicts poor prognosis in hepatocellular carcinoma. Cancer Manag Res 2019; 11: 2795-802.

36. Song Y, Guo Q, Gao S, Hua K. MiR-454-3p promotes proliferation and induces apoptosis in human cervical cancer cells by targeting TRIM3. Biochemical and Biophysical Research Communications 2019;516(3):872-9.

37. Liangliang R, Han C, Junwei $S$, Xuhong $C$, Chun L, Xiaolan Z, Ning $\mathrm{H}$ et al. MiR-454-3p-Mediated Wnt/ $\beta$-catenin Signaling Antagonists Suppression Promotes Breast Cancer Metastasis. Theranostics 2019;9(2):449-65.

38. Naiyuan S, Lei W, Lian X, Rong W, Qing L. Plasma miR-454-3p as a potential prognostic indicator in human glioma. Neurological Sciences 2015;36:309-13.

39. Eedunuri VK, Rajapakshe K, Fiskus W, Geng C, Chew SA, Foley C. miR137 Targets p160 Steroid Receptor Coactivators SRC1, SRC2, and SRC3 and Inhibits Cell Proliferation. Mol Endocrinol 2015;29(8):1170-83.

40. Li Y, Qiming H, Xuehui S, Xiang j, Xiaolin X et al. MicroRNA 145 may play an important role in uveal melanoma cell growth by potentially targeting insulin receptor substrate-1. Chin Med J (Engl) 2014;127(8):1410-6.

41. Sun L, Bian G, Meng Z, Dang G, Shi D, Mi S. MiR-144 Inhibits Uveal Melanoma Cell Proliferation and Invasion by Regulating c-Met Expression. PLoS One 2015;10(5):e0124428. doi: 10.1371/journal. pone.0124428. eCollection 2015.

42. Venza, Visalli M, Beninati C, Benfatto $S$, Teti D, Venza I et al. miR-92a-3p and MYCBP2 are involved in MS-275-induced and c-myc-mediated TRAIL-sensitivity in melanoma cells. Int Immunopharmacol 2016;40:235-43.

43. Wang X, Hu Y, Cui J, Zhou Y, Chen L. Coordinated targeting of MMP-2/ MMP-9 by miR-296-3p/FOXCUT exerts tumor-suppressing effects in choroidal malignant melanoma. Mol Cell Biochem 2018;445(1-2):25-33.

44. Zhou J, Hu Y, Cui J, Zhou Y, Chen L. Oncogenic role of microRNA20a in human uveal melanoma. Mol Med Rep 2016;14(2):1560-6.

45. Ling JW, Lu PR, Zhang YB, Jiang S, Zhang ZC. miR-367 promotes uveal melanoma cell proliferation and migration by regulating PTEN. Genet Mol Res 2017;16(3). doi: 10.4238/gmr16039067.

46. Li J, Liu X, Li C, Wang W. miR-224-5p inhibits proliferation, migration, and invasion by targeting PIK3R3/AKT3 in uveal melanoma. J Cell Biochem 2019;120(8):12412-21.

47. Wang YC, Yang X, Wei WB, Xu XL. Role of microRNA-21 in uveal melanoma cell invasion and metastasis by regulating $\mathrm{p} 53$ and its downstream protein. Int J Ophthalmol 2018;11(8):1258-68.

48. Wang Y, Luo Y, Guan W, Zhao H. Role of miR-23a/Zeb1 negative feedback loop in regulating epithelial-mesenchymal transition and tumorigenicity of intraocular tumors. Oncol Lett 2018;16(2):2462-70.

49. Ilangumaran, S, Villalobos-Hernandez A, Bobbala, D, Ramanathan S. The hepatocyte growth factor (HGF)-MET receptor tyrosine kinase signaling pathway: Diverse roles in modulating immune cell functions. Cytokine 2016;82:125-39. 